\title{
BWP Bats: A marketing case study of maple bats in Major League Baseball
}

\author{
Mary Catherine Colley \\ Troy University \\ Martie Schrimsher \\ Troy University
}

\begin{abstract}
Brookville Wood Products (BWP) is a company created in 1965 and located in rural Pennsylvania. The company grows ash and maple trees on their 5,000 acres of land and sold timber to furniture manufacturers in the United States. In the late 1990s, BWP reduced their workforce due to furniture manufacturing moving to China. To stay in business, the company diversified into making baseball bats with a customer focus on the Major League Baseball teams. The case begins with the creation of BWP Bats in 1999 and the introduction of the maple bat to Major League Baseball players, followed by an analysis of their marketing challenges.
\end{abstract}

\section{INTRODUCTION}

Since 1965 Joseph and Monica Mitchell have owned and operated the Brookville Wood Products (BWP) sawmill in the rural town of Brookville, Pennsylvania. In a city with less than 4,000 people, the company harvests and processes wood from their own 5,000 acres located in the country's prime lumber belt. For decades their main revenue source came from selling maple, ash, and oak timber to the furniture sector. In addition, they had begun selling billets to Louisville Slugger and other bat manufacturers to produce bats.

In the late 1990s stiff competition from the furniture industry in China forced the company rethink their overall business strategy (Shuler and Buehlmann, 2002). During this period, the company reduced their workforce from 250 to 100 employees. To remain profitable they decided in 1999 to diversify and created a subsidiary of BWP to produce baseball bats called BWP Bats. This opportunity fit well into their company's strengths, played a part in an integrative growth strategy for the company, and provided a competitive advantage since they (unlike other bat manufacturers) actually own the hardwoods. To prepare for the move in this direction the company received advice from Louisville Slugger to learn "how to select the appropriate wood, how to use lathes to turn billets into bats, and how to finish the bats" (Belson, 2010).

\footnotetext{
About the BWP Bats

BWP Bats was created as a boutique bat manufacturing company. The Mitchell's nephew, Mike Gregory, stepped in as Vice President to oversee, operate, and grow the business. "BWP Bats, LLC operates in correlation with BWP. We operate with two sawmills, several dry kilns, and complete
} 
finishing lines" (BWP Bats, 2018). The bats start as logs and finish up as bats and "we have control throughout the entire process, which is truly unique to the marketplace" (BWP Bats, 2018).

BWP Bats now produces over 40,000 bats a year with $30 \%$ of their production used by professional baseball players (Cheney, 2018). The remaining supply is sold in many retail outlets, but the focus of their business strategy is to sell their product to the major and minor league baseball teams and use the success of their bats on the field as a promotion tool. Bat production operated at $50 \%$ capacity which is 750 bats a week, leaving ample room to grow and create more demand for their product.

BWP Bats "(is) a truly unique wooden bat manufacturer because of their location, state of the art manufacturing processes, and strict attention to detail which enables them to provide the highest quality of bats available to the marketplace" ("About BWP Bats", 2018). The slogan for BWP is "Serious Bats for Serious People". Their product is sold to more than 150 major and minor league baseball players (less than $5 \%$ of the market) as well as recreational players, and can be found in 50 states and 20 countries. The three types of bat they offer are maple, ash, and oak, with maple accounting for $80 \%$ of their sales volume. The remaining sales are mostly ash.

\section{MAJOR LEAGUE BASEBALL AND THE DEMAND FOR BATS}

The two types of bats typically used in the major leagues today are ash and maple, but bats have historically been made of ash as far back as the 1800's. Maple was introduced only in the last two decades. Ash trees that are grown in dense clusters are the best for making bats. Forty to fifty years of growth is required to bring an ash tree to the preferred trunk diameter of 14-16 inches; and when grown to optimal size, each tree can yield about sixty bats ("How Products Are Made", 2018). However, only half of what is cut in the forest is ultimately used to make baseball bats ("How Products Are Made" 2018). For BWP Bats less than $20 \%$ of the trees harvested are considered suitable for bat production ("About BWP Bats", 2018).

An ash bat is not quite as hard as a maple bat, but they offer a lot more flex when a hitter swings. This creates a "trampoline effect" meaning that the ball will go farther. This effect is the greatest asset and biggest flaw of ash bats because it causes the bat to die and lowers the life of the bat" ("Top 10 Best Wood Bats", 2018). The flex of the wood limits the usability and life of the bat to approximately a week before it breaks or dents.

A significant threat to the ash bat market is in the supply of ash trees. An insect called the ash emerald borer appeared in the United States in 2002 and is practically impossible to get rid of. The emerald ash borer can kill a tree in two to three years. "The insect has killed trees in 32 states and in Canadian provinces. America only has about 8.7 billion ash trees left and only $1 \%$ are expected to survive" ("Ash trees' days are numbered," 2018). "Recent discoveries of the insect in Pennsylvania have caused the forest industry to implement restrictions on wood being transported in and out of the state" (King, 2011). Also, as the temperatures rise, the ash wood that now makes an ideally dense but flexible bat might turn softer because of a longer growing season (Davey, 2007).

\section{INTRODUCTION AND USE OF THE MAPLE BAT IN THE MAJOR LEAGUES}

Maple is used to make bats because its extreme hardness brings an extra punch and an increased durability to the bat and they tend to last four times as long as an ash bat (Malloy, 2008). "(Maple) is very hard and dense and creates a higher 'exit speed' when the ball comes off the bat. Maple bats are less likely to splinter, and (should) last longer" ("Top Ten Best Wood Bats", 2018). When comparing the price of maple versus ash bats maple bats cost only five to twenty dollars more than an ash bat. The relatively small difference in price, plus the fact that maple bats last four times as long as an ash bat, the economics are clear.

Maple bats were introduced to the major leagues by Sam Holman of Sam Bats. Although maple bats had not yet been approved by Major League Baseball, Joe Carter of the Toronto Blue Jays sneaked a Sam Bat into a game in 1997 (Curry, 1998). The approval by the major league industry came one year later, 
but the popularity of maple bats skyrocketed when Barry Bonds started using Sam Bats maple bats in 2001. Bonds went on to break the world record for most home runs in a season. Bonds' record breaking season brought attention to the fact that he was using a unique maple baseball. In no time at all, the maple bat craze had begun.

Even though steroid use by Bonds created an issue for the baseball player years later, at the time maple bats were given high praise as a part of assisting in Bonds' accomplishments on the field. With Bonds' celebrity status comes a high demand for maple bats. For example, in 2006 the popularity of maple bats had grown so much that for the first time, at least for one bat manufacturer, the demand for maple bats exceeded demand for ash bats (Curry, 2006). The vast majority of bats used by MLB players are ash and maple, and by 2010 half of all major leaguers used maple bats (Dvorchak, 2010).

The reduction in supply of ash bats over the years and the improved performance of the maple bat has had an effect on the types of bats desired in the Major League Baseball teams. Ash bat production for the major leagues dropped to 50,000 in 2010, then to 25,000 in 2014. Today, in 2018, ash bat production is only at 10,000 (Fitzpatrick, 2018). Therefore, creating and finding comparable alternatives is critical to the livelihood of the baseball bat industry.

\section{MARKET SHARE OF BAT BRANDS IN THE MAJOR BASEBALL LEAGUE}

In 1993 there were just ten licensed bat manufacturers selling to the major and minor leagues (Glier, 2013). As of 2018, there were a total of 93 bat manufacturers, but only 30 service the Major Baseball League because of strict regulations that must be met (Biba, 2018). With 30 Major League Baseball teams in the United States, and including each associated minor league team, there is an average of 120 players for each team, bringing the total number of professional baseball players to about 3,600 players. Each major league player will go through 120 to 140 bats in just one season for an average price of $\$ 100$ a bat (Neff, 2013).

BWP Bats plans to continue growing their market in the major leagues. In 2010, BWP Bats was the second largest supplier of bats to the minor leagues and has contracts with over 200 major and minor baseball players (Dvorchak, 2010). The company continues to hone their craft using technology to create the perfect bat.

\section{SHATTER ISSUES OF MAPLE BATS IN THE MAJOR LEAGUES AND THE IMPACT ON POLICY}

According to Mike Gregory, Vice President of BWP Bats, Major League players like maple for its harder feel and longer life. However, maple bats are also more likely to explode when they shatter, while ash bats more often splinter into small fragments" (Belson, 2010). This caused some concern and some policy changes in Major League Baseball.

Before 2008, events regarding broken maple bats and their danger to both fans and players caused MLB to make policy changes to control the quality of bats used in the major leagues and create an inspection program. To pay for this program Major League Baseball doubled the annual fee bat manufacturers must pay to sell to the major leagues. In addition, companies also must carry $\$ 10$ million in liability insurance. Along with a $\$ 14,000$ application fees up front, the buy-in is roughly $\$ 30,000$ (Ward, Kramer, Stevens, 2017). This insurance increase resulted in an additional cost for BWP Bats and other maple bat suppliers to the MLB and minor leagues (Belson, K., 2010).

The problem with maple bats is the way they explode when they break. All wooden bats are subject to break and they can even be hurled into the field, the dugout, or the stands when they break. Maple bats started "exploding" at the rate of about one a game in 2008 which led to serious injuries (Belson, $2010 \mathrm{~b}$ ). Maple bats shatter into shards that explode on contact with a baseball. "The maple bats, because of a denser cell structure, do not crack like ash bats but break apart, with the jagged barrel piece typically flying up to 100 feet in any direction" ("Major League Baseballs...", n.d.). 
If nothing changed, maple bats were in danger of being banned from the major leagues, thus destroying the livelihood of several small bat manufacturers.

"For years bat makers were unable to make baseball bats from maple due to the high moisture content of the wood. Despite the high strength it was simply too heavy to make into a baseball bat. In the late 90's technology came to the rescue and high tech wood kilns now remove enough moisture from the wood to make high quality, high strength maple baseball bats. Today, maple bats are increasingly favored by amateur and major league players alike" ("Wood Bats", n.d., p.3)

With a focus on researching the straightness of the wood grain of maple and the use of other technologies, improvements were seen almost immediately. In the 2009 season, the percent of maple bats breaking fell 35 percent. In 2010 the number of broken maple bats declined an additional 15 percent (Belson, $2010 \mathrm{~b}$ ). The decline in the number of broken bats can be attributed mostly to the host of rules and required audits that were introduced in 2009 which forced manufacturers to make changes in production. The focus on research and technology saved many small bat manufacturers from going out of business.

\section{CONCLUSION}

BWP Bats explored different but related options for their business as competition from China threatened their livelihood in the furniture industry. The company chose to diversify outside of their comfort zone, focusing on integrative growth strategies to keep their timber business in operation. They chose a product whose customers are known to be fickle and superstitious about their bats. Baseball players can tell when a baseball bat is off by one millimeter, and if the bat does not "sound" right, they will not use it. As such, good customer relationship strategies, consistencies in production, and a player's success on the baseball field make for a successful bat manufacturer.

\section{REFERENCES}

Ash trees' days are numbered, just like the elms. (2018, Apr 12). Editorial. Retrieved from https://www.stowetoday.com/news_and_citizen/opinion/editorials/ash-trees-days-are-numberedjust-like-the-elms/article_c8b52538-3e6a-11e8-93a2-4ffd730423d6.html

Belson, K. (2010a, September 20). Colvin's injury highlights danger when wooden bats break. The New York Times. Retrieved from https://www.nytimes.com/2010/09/21/sports/baseball/21 colvin.html

Belson, K. (2010b, March 23). Making baseball bats a big seller. The New York Times. Retrieved from https://www.nytimes.com/2010/03/24/sports/baseball/24lumber.html

Biba, J. (2018, January 22). Childhood Friends Resurrect Fletcher Baseball Bat Company. Retrieved from http:/www.blueridgenow.com/news/20180121/childhood-friends-resurrect-fletcherbaseball-bat-company

BWP Bats "About," (n.d.). Retrieved from http://www. bwpbats.com/about.html

BWP Bats "Production," (n.d.). Retrieved from http://www.bwpbats.com/ production.html

Cheney, J. (2018, July 7). A major league factory: Taking a tour of BWP Bats' factory. Retrieved from https://uncoveringpa.com/tour-bwp-bats.

Curry, J. (1998, June 19). Need good wood? A batmaker tried maple. The New York Times. Retrieved from https://www.nytimes.com/1998/06/19/sports/need-good-wood-a-batmaker-tries-maple.html

Curry, J. (2006, November 24). Bat maker wants to sell company on his terms. The New York Times. Retrieved from https://www.nytimes.com/2006/11/24/sports/baseball/24bats.html

Davey, M. (2007, July 11). Beloved ash bats threatened by pest, warming. San Diego Tribune. Retrieved from http://legacy.sandiegouniontribune.com/uniontrib/20070711/ news_1n11bats.html 
Dvorchak, R. (2010, July 4). Bat maker a big hit with the pros: Jefferson county company has made inroads with maple bats over the past decade in major leagues. Pittsburgh Post-Gazette. Retrieved from http://old.post-gazette.com/pg/10185/1070388-63.stm

Fitzpatrick, F. (2018, June 14). An industry in ashes: A Pennsylvania tradition is dying, one baseball bat at a time. York Dispatch. Retrieved from https://www.yorkdispatch.com/ story/sports/baseball/2018/06/14/industry-ashes-pa-tradition-dying-one-baseball-battime/701217002/

Glier, R. (2013, October 1). Louisville Slugger losing grip as bat of choice. Special for USA TODAY Sports. Retrieved from https://www.usatoday.com/story/sports/mlb/2013/10/01/ louisvilleslugger-marucci-bats/2905151/

How products are made: Baseball bats. (n.d.). Retrieved from http://www.madehow.com/ Volume2/Baseball-Bat.html.

King, M. (2011, June). Tiny beetle big problem: DEC battles the emerald ash borer. New York State Conservationist, 24-27.

Major league baseball's liability for injuries resulting from shattering maple bats. Levine and Slavit, Attorneys. (n.d.). Retrieved from https://www.newyorkinjuries.com/2008/06/25/injuries-frombaseball-bats/

Malloy, D. (2008, July 13). Maple bats a splintering controversy around the majors. Pittsburgh PostGazette. Retrieved from http://www.post-gazette.com/sports/2008/07/13/Maple-bats-asplintering-controversy-around-the-majors/stories/200807130158

Neff, J. (2013, April 1). Inside Lousiville Slugger's game plan to beat upstart rivals, score young players. AdAge. Retrieved from http://adage.com/article/cmo-interviews/marketing-louisville-slugger-splan-lure-young-players/240608/

Shuler, A., \& Buelmann, U. (2003, March). Identifying Future competitive business strategies for U.S. residential wood furniture industry: Benchmarking and paradigm shifts. USDA Forest Service. Retrieved from https://www. iatp.org/files/Identifying_Future_Competitive_Business_Strate.pdf

Top 10 best wood bats: Wooden bats brands and review (2018, April 23). Retrieved from https:// batandballgame.com/best-wood-bats/

Ward, M., Kramar, A., \& Stevens, A. (2017, October 17). How a Maine carpenter's side gig became a \$2 million baseball bat business. CNBC. Retrieved from https://www.cnbc.com/ 2017/10/17/how-amaine-carpenters-side-gig-became-a-2-million-baseball-bat-business.html

Wood Bats. (n.d.). Retrieved from http://baseballbats.net/how-to-choose-a-baseball-bat/types-ofbats/wood-bats/

\section{APPENDIX A}

\section{Case Note Discussion}

The case discussion objectives or questions for students can be as follows:

1. Analyze the advantages and disadvantages of ash versus maple bats.

2. Create and analyze a SWOT for BWP Bats.

3. Create and analyze a PESTLE analysis of the bat manufacturing industry.

4. Research, list, and discuss the unique challenges baseball bat manufacturers have in marketing to baseball players in MLB and minor league? For example, what is important for an MLB player when choosing a bat? What makes a baseball player a unique customer? How can a bat manufacturer utilize this information to improve their marketing strategy?

These questions can be answered from the case or the professor can ask for additional research to be conducted. 